\title{
FAKTOR-FAKTOR YANG BERHUBUNGAN DENGAN KEJADIAN KURANG ENERGI KRONIK (KEK) PADA IBU HAMIL DI WILAYAH KERJA UPTD PUSKESMAS JATILUHUR PURWAKARTA TAHUN 2017
}

\author{
Rusmalina Fuspita Rini' ${ }^{1}$, Tomi Herutomo ${ }^{2 *}$, Irwan Haryanto ${ }^{3}$ \\ 1,2,3 Sekolah Tinggi Ilmu Kesehatan Holistik \\ *Korespondensi: Jl. Veteran No.272 Ciseureuh Purwakarta, Email: tomiherutomo@yahoo.com
}

\begin{abstract}
ABSTRAK
Latar Belakang: Tingginya Kejadian Kurang Energi Kronik (KEK) Pada Ibu Hamil di Indonesia bisa mengakibatkan risiko dan komplikasi pada ibu hamil dan anak yang dikandungnya seperti ibu melahirkan BBLR, anemia pada bayi, mudah terserang infeksi, abortus, terhambatnya pertumbuhan otak janin dan akan meningkatkan angka kematian ibu. Di Kabupaten Purwakarta angka Kejadian Kurang Energi Kronik (KEK) pada ibu hamil masih tinggi, salah satunya di Wilayah Kerja UPTD Puskesmas Jatiluhur Purwakarta Tahun 2017 jumlah Ibu Hamil KEK sebanyak 74 orang atau $(5,07 \%)$.

Tujuan Penelitian: Mendeskripsikan faktor-faktor yang berhubungan dengan kejadian Kurang Energi Kronik (KEK) pada ibu hamil di Wilayah Kerja UPTD Puskesmas Jatiluhur Purwakarta tahun 2017.

Metode: Desain Penelitian adalah cross sectional. Subjek penelitian adalah Ibu hamil dengan kejadian Kurang Energi Kronik (KEK) di Wilayah Kerja UPTD Puskesmas Jatiluhur Purwakarta Tahun 2017 yang berjumlah 35 orang, dan besarnya sampel pembanding ibu hamil Tidak KEK di Wilayah Kerja UPTD Puskesmas Jatiluhur Purwakarta sebanyak 35 orang sehingga total sampel keseluruhan sebanyak 70 orang ibu hamil. Pengumpulan data menggunakan kuesioner yang berisikan pertanyaan tentang total energi, asupan protein, kebiasaan merokok, konsumsi minuman beralkohol, paritas, jarak kehamilan, umur, penyakit infeksi, aktivitas fisik, tingkat pendidikan, pengetahuan, pendapatan, dan Indeks Masa Tubuh (IMT). Analisis data menggunakan uji Chi-Square.

Hasil: Faktor-faktor yang berhubungan dengan Kejadian Kurang Energi Kronik pada ibu hamil adalah Total Energi ( $p=0,004, P R=0,410)$, Asupan protein $(p=0,001, P R=2,053)$ bahwa dapat dikatakan dua kali lipat risiko terjadinya KEK pada ibu hamil apabila asupan protein $(<68 \%)$, Paritas ( $\mathrm{p}=0,024, \mathrm{PR}=0,410)$, sedangkan faktor-faktor yang tidak berhubungan dengan KEK pada ibu hamil adalah Jarak Kehamilan $(\mathrm{p}=0,148, P R=0,666)$, Umur $(\mathrm{p}=0,087, P R=1,6)$, Penyakit Infeksi $(p=0,156, P R=1,521)$, Tingkat Pendidikan $(p=0,000, P R=0,703)$, Pengetahuan $(p=0,148$, $P R=0,666)$, dan Pendapatan ( $p=0,000, P R=0,703)$.
\end{abstract}

Simpulan: Ada Hubungan antara Total Energi, Asupan Protein, dan Paritas dengan kejadian Kurang Energi Kronik (KEK) pada Ibu Hamil.

Kata kunci: Kurang Energi Kronik (KEK), faktor-faktor yang berhubungan dengan kejadian Kurang Energi Kronik (KEK) pada ibu hamil

\footnotetext{
ABSTRACT

Background: The high incidence of Chronic Energy Deficiency (CED) in pregnant women in Indonesia could result in risks and complications in pregnant women and children they contain such as maternal anaemia, LOW BIRTH WEIGHT in infants, susceptible to infection, abort, terhambatnya Fetal brain growth and will increase maternal mortality. Purwakarta Regency, Incidence figures in Chronic Energy Deficiency (CED) in pregnant women, one of whom is still high in the area Work UNIT for Clinics Jatiluhur Purwakarta Year 2017 the number of pregnant women BEING BEATEN as many as 74 people or (5.07\%).

Objective: Describe the factors related to the incidence of Chronic Energy Deficiency (CED) in pregnant women in areas of Work UNIT for Clinics Jatiluhur Purwakarta year 2017.

Method: Design research is a cross sectional. The subject is pregnant with Chronic Energy Deficiency (CED) in the working area health centers UNIT for Jatiluhur Purwakarta Year 2017 of 35 people, and the magnitude of the comparison samples of pregnant women do not Work in the
} 
area of DOMESTIC VIOLENCE UNIT for Clinics Jatiluhur As many as 35 people so it purwakarta total sample overall as much as 70 people of pregnant women. Data collection using a questionnaire containing questions about total energy, protein intake, smoking habits, alcohol consumption, parity, age, pregnancy, infectious diseases, physical activity, level of education, knowledge, income, and index the time body (IMT). Analysis of test data using the Chi-Square.

Result: Factors related to the incidence of chronic less energy is the Total energy of pregnant women ( $p=0,004, P R=0,410)$, protein intake $(p=0.001, P R=2,053)$ that can be said to be twofold risk of VIOLENCE in pregnant women when the intake of protein $(<68 \%)$, parity $(p=0,024$, $P R=0,410)$, whereas the factors that are not related to VIOLENCE in pregnant women is the distance of pregnancy $(p=0,148, P R=0,666)$, age $(p=0,087, P R=1,6)$, infectious diseases $(p=$ $0,156, P R=1,521)$, level of education ( $p=0.000, P R=0.703)$, knowledge $(p=0,148, P R=0,666)$, and income ( $p=0.000, P R=0,703)$.

Conclusion: There is a relationship between Total energy, Protein intake, and Parity with Chronic Energy Deficiency (CED) in pregnant women.

Keywords: Chronic Energy Deficiency (CED), factors related to the incidence of Chronic Energy Deficiency (CED) in pregnant women

\section{PENDAHULUAN}

Kekurangan Energi Kronis (KEK) adalah keadaan dimana ibu menderita keadaan kekurangan makanan yang berlangsung menahun (kronis) yang mengakibatkan timbulnya gangguan kesehatan pada ibu. ${ }^{1}$ KEK merupakan gambaran status gizi ibu di masa lalu, kekurangan gizi kronis pada masa anakanak baik disertai sakit yang berulang, akan menyebabkan bentuk tubuh yang kuntet (stunting) atau kurus (wasting) pada saat dewasa. Ibu yang memiliki postur tubuh seperti ini berisiko mengalami gangguan pada masa kehamilan dan melahirkan bayi BBLR. $^{2}$

Berdasarkan hasil survei Riskesdas tahun 2007 prevalensi ibu hamil yang mengalami KEK di Jawa Barat adalah 14,30\%. ${ }^{3}$ Pada tahun 2010 untuk wilayah Jawa Barat prevalensi ibu hamil KEK mencapai 20,13\%,4 sedangkan pada tahun 2013 untuk wilayah Jawa Barat prevalensi ibu hamil KEK $30,1 \% 5$ bila dibandingkan dengan jumlah ibu hamil KEK di Kabupaten Purwakarta pada tahun 2016 sebanyak 19,976 orang atau 6,7\% (Profil Dinkes Purwakarta 2016). Berdasarkan data awal yang didapatkan dari Profil Puskesmas Jatiluhur, pada tahun 2016 jumlah ibu hamil sebanyak 1.459 orang. Jumlah Ibu Hamil KEK sebanyak 74 orang atau (5,07\%).

Berdasarkan latar belakang di atas tingginya ibu hamil KEK dapat mengakibatkan risiko melahirkan BBLR, keguguran, abortus, bayi lahir mati, dan cacat bawaan. Kabupaten Purwakarta mempunyai angka kejadian ibu hamil KEK masih sangat tinggi, salah satunya di UPTD Puskesmas Jatiluhur. Oleh karena itu, peneliti tertarik untuk melakukan penelitian tentang "Faktor-faktor yang berhubungan dengan kejadian Kurang Energi Kronik (KEK) Pada Ibu Hamil di Wilayah Kerja UPTD Puskesmas Jatiluhur Purwakarta Tahun 2017".

\section{METODE PENELITIAN}

Jenis penelitian yang digunakan pada penelitian ini yaitu cross sectional dengan menggunakan pendekatan observasional analitik yaitu jenis penelitian hanya melakukan observasi dan pengukuran variabel pada satu saat tertentu saja. Dalam penelitian ini yang menjadi populasi adalah jumlah keseluruhan ibu hamil periode tahun 2016 bulan Januari sampai dengan bulan Desember yaitu sebanyak 74 orang atau $(5,07 \%)$ ibu hamil Kurang Energi Kronik (KEK) di Wilayah Kerja UPTD Puskesmas Jatiluhur Kabupaten Purwakarta. Kriteria inklusi yaitu Ibu hamil yang mengalami KEK dengan LILA $<23,5$ $\mathrm{cm}$, Ibu hamil bersedia menjadi responden. Kriteria Eksklusi yaitu Tidak ada ibu hamil KEK yang mengundurkan diri. Instrumen yang digunakan adalah kuesioner, data diperoleh melalui wawancara. Analisis penelitian analisis univariat untuk melihat distribusi frekuensi dan analisis bivariat untuk melihat adanya hubungan. 


\section{HASIL PENELITIAN}

Faktor - faktor yang berhubungan dengan kejadian Kurang Energi Kronik (KEK) pada Ibu Hamil di Wilayah Kerja UPTD Puskesmas Jatilihur Purwakarta Tahun 2017

\begin{tabular}{|c|c|c|c|c|c|c|c|}
\hline \multirow{2}{*}{ NO } & \multirow{2}{*}{ Variabel } & \multicolumn{2}{|c|}{ KEK } & \multicolumn{2}{|c|}{ Tidak KEK } & \multirow[b]{2}{*}{$\mathbf{P}$} & \multirow[b]{2}{*}{ PR } \\
\hline & & $\mathbf{n}$ & $\%$ & $\mathbf{n}$ & $\%$ & & \\
\hline \multirow[t]{3}{*}{1} & Total Energi & & & & & & \\
\hline & a. Kurang $(<70 \%)$ & 15 & 42,5 & 5 & 14,3 & $0,004^{\mathrm{a}}$ & 0,410 \\
\hline & b. Baik (>70-100\%) & 20 & 57,1 & 30 & 85,7 & & \\
\hline \multirow[t]{3}{*}{2} & Asupan Protein & & & & & & \\
\hline & a. Kurang $(<68 \%)$ & 17 & 48,6 & 5 & 14,3 & $0,001^{\mathrm{a}}$ & 2,053 \\
\hline & b. Baik (>68-100\%) & 18 & 51,4 & 30 & 85,7 & & \\
\hline \multirow[t]{3}{*}{3} & Paritas & & & & & & \\
\hline & a. Berisiko, jika > 3 kali & 3 & 8,6 & 10 & 28,6 & $0,024^{\mathrm{a}}$ & 0,410 \\
\hline & b. Tidak Berisiko, jika $<3$ kali & 32 & 91,4 & 25 & 71,4 & & \\
\hline \multirow[t]{4}{*}{4} & Jarak Kehamilan & & & & & & \\
\hline & a. Berisiko, jika jarak < 2 & 7 & 20,0 & 12 & 34,3 & $0,148^{a}$ & 0,666 \\
\hline & tahun & 28 & 80,20 & 23 & 65,7 & & \\
\hline & $\begin{array}{l}\text { b. Tidak Berisiko, jika jarak }>2 \\
\text { tahun }\end{array}$ & & & & & & \\
\hline \multirow[t]{3}{*}{5} & Umur & & & & & & \\
\hline & $\begin{array}{l}\text { a. Berisiko, }<20 \text { tahun, atau }> \\
35 \text { tahun }\end{array}$ & 8 & 22,9 & 3 & 8,6 & $0,087^{a}$ & 1,6 \\
\hline & $\begin{array}{l}\text { b. Tidak Berisiko, } 20 \text { tahun - } \\
35 \text { tahun }\end{array}$ & 27 & 77,1 & 32 & 91,4 & & \\
\hline \multirow[t]{3}{*}{6} & Penyakit Infeksi & & & & & & \\
\hline & a. Ya & 7 & 20,0 & 3 & 8,6 & $0,156^{\mathrm{a}}$ & 1,521 \\
\hline & b. Tidak & 28 & 80,0 & 32 & 91,4 & & \\
\hline \multirow[t]{3}{*}{7} & Tingkat Pendidikan & & & & & & \\
\hline & a. Pendidikan Dasar SD/SMP & 24 & 68,6 & 29 & 81,0 & $0,000^{\mathrm{a}}$ & 0,703 \\
\hline & b. Pendidikan & 11 & 31,4 & 6 & 19,0 & & \\
\hline & Menengah/T & & & & & & \\
\hline \multirow{3}{*}{8} & Pengetahuan & & & & & & \\
\hline & a. $<\operatorname{median}(11,5)$ & 7 & 20,0 & 12 & 34,3 & $0,148^{\mathrm{a}}$ & 0,666 \\
\hline & b. > median $(11,5)$ & 28 & 80,20 & 23 & 65,7 & & \\
\hline \multirow[t]{3}{*}{9} & Pendapatan & & & & & & \\
\hline & a. < Upah Minimum Regional & 24 & 68,6 & 29 & 81,0 & $0,000^{\mathrm{a}}$ & 0,703 \\
\hline & b. > Upah Minimum Regional & 11 & 31,4 & 6 & 19,0 & & \\
\hline
\end{tabular}

Keterangan:

$\mathrm{a}=$ Pearson Chi-Square

$\mathrm{b}=$ Fisher's Exact Test

\section{PEMBAHASAN}

\section{Hubungan Total Energi dengan Kejadian KEK pada Ibu Hamil}

Kurang Energi Kronik (KEK) adalah suatu keadaan patologis akibat kekurangan zat gizi (malnutrisi). Mekanisme timbulnya kekurangan energi kronik berawal dari faktor lingkungan dan manusia yang didukung dengan kurangnya konsumsi zat gizi pada tubuh, jika hal itu terjadi maka simpanan zat-zat pada tubuh akan digunakan untuk memenuhi kebutuhan dan bila keadaan itu terus berlangsung lama, maka simpanan zat gizi tersebut akan habis. ${ }^{6}$ Total energi dalam penelitian ini berhubungan dengan kejadian KEK pada ibu hamil, dari hasil penelitian diketahui bahwa total energi responden terhadap kejadian KEK pada ibu hamil sebesar $(42,5 \%)$ termasuk kurang, sedangkan $(57,1 \%)$ total energi termasuk baik, dan nilai $(\mathrm{P}=0,004, \mathrm{PR}=0,410)$.

Hasil penelitian sejalan dengan penelitian Halym Surasih (2005) bahwa dikatakan ada hubungan yang signifikan antara jumlah konsumsi energi dengan kejadian KEK pada ibu hamil di Kabupaten Banjarnegara tahun 2005, karena jika 
masukan zat gizi dari makanan tidak seimbang dengan kebutuhan tubuh maka akan terjadi defiseinsi zat gizi. ${ }^{7}$ Dari hasil analisis diperoleh nilai $(\mathrm{p}=0.005) \mathrm{PR}=9,793$ dengan maka ibu hamil yang jumlah konsumsi energinya $(<70 \%$ AKG $)$ mempunyai risiko untuk terkena KEK sebesar 9,793 kali dibandingkan dengan ibu hamil yang jumlah konsumsi energi nya (> 70-100\%).

\section{Hubungan Asupan Protein dengan Kejadian KEK pada ibu Hamil}

Asupan protein bagi ibu hamil sangat penting, kebutuhan protein selama hamil meningkat sampai 30 gram, protein digunakan dalam perkembangan janin, penambahan volum darah, dan pertumbuhan mamae, serta jaringan uterus. $^{8}$ Asupan protein dalam penelitian ini berhubungan dengan kejadian KEK pada ibu hamil, dari hasil penelitian diketahui bahwa asupan protein responden terhadap kejadian KEK pada ibu hamil sebesar $(48,6 \%)$ termasuk kurang, sedangkan $(51,4 \%)$ termasuk baik, dan nilai $(\mathrm{p}=0,001$, $\mathrm{PR}=2,053$ ) bahwa dapat dikatakan dua kali lipat risiko terjadinya KEK pada ibu hamil apabila asupan protein $(<68 \%)$.

Hasil penelitian ini sejalan dengan penelitian Agustian Nur Efrinita (2010) menunjukkan ada hubungan yang bermakna antara asupan protein dengan risiko KEK pada ibu hamil di Kecamatan Jebres Surakarta, karena apabila kekurangan asupan protein dalam jangka waktu tertentu akan mempengaruhi status gizi dan dengan demikian fungsi protein yaitu untuk memacu pertumbuhan, sumber pokok jaringan, pembentukan hormone, enzim dan antibody tidak dapat bekerja secara maksimal. 9 Persentase ibu hamil risiko KEK lebih banyak terjadi pada ibu hamil dengan asupan protein kurang dibanding ibu hamil dengan asupan protein baik. Selain itu, protein juga merupakan faktor dominan yang berhubungan dengan risiko KEK dimana ibu hamil dengan asupan protein kurang mempunyai risiko KEK 13.416 kali dibandingkan dengan ibu hamil yang asupan proteinnya baik.

\section{Hubungan Paritas dengan kejadian KEK pada ibu Hamil}

Paritas adalah berapa kali seorang ibu telah melahirkan. Dalam hal ini ibu dikatakan terlalu banyak melahirkan adalah lebih dari 3 kali. Paritas (jumlah anak) merupakan keadaan wanita yang berkaitan dengan jumlah anak yang dilahirkan. Paritas juga merupakan salah satu faktor yang mempengaruhi status gizi ibu hamil. ${ }^{10}$ Paritas dalam penelitian ini berhubungan dengan kejadian KEK pada ibu hamil, dari hasil penelitian diketahui bahwa paritas terhadap kejadian KEK pada ibu hamil sebesar (8,6\%) berisiko, sedangkan $(91,4 \%)$ tidak berisiko dan nilai $(p=0,024$, $\mathrm{PR}=0,410$ ).

Hasil penelitian ini sejalan dengan penelitian Marlenywati (2010) bahwa dapat dikatakan ada hubungan yang signifikan antara paritas dengan kejadian KEK pada ibu hamil di Kota Pontianak, dari hasil analisis diperoleh $(p=0,045)$ secara statistik terdapat hubungan yang bermakna antara paritas dengan kejadian KEK pada ibu hamil. 11

\section{Hubungan Jarak Kehamilan dengan kejadian KEK pada ibu Hamil}

Jarak kehamilan adalah tiap berapa tahun seorang ibu hamil. Ibu dikatakan terlalu sering hamil bila jaraknya kurang dari 2 tahun. Penelitian menunjukkan bahwa apabila keluarga dapat mengatur jarak antara kehamilan anaknya lebih dari 2 tahun maka anak akan memiliki probabilitas hidup lebih tinggi dan kondisi anaknya lebih sehat dibanding anak dengan jarak kehamilan dibawah dua tahun.12 Jarak kehamilan dalam penelitian ini tidak berhubungan dengan kejadian KEK pada ibu hamil, dari hasil penelitian diketahui bahwa jarak kehamilan responden terhadap kejadian KEK pada ibu hamil sebesar $(20,0)$ jarak kehamilan berisiko, sedangkan $(80,20)$, jarak kehamilan tidak berisiko dan nilai $(\mathrm{p}=0,148, \mathrm{PR}=0,666)$.

Hasil penelitian ini sejalan dengan penelitian Halym Surasih (2005) bahwa tidak ada hubungan yang signifikan antara jarak kehamilan dengan kejadian KEK pada ibu hamil di Kabupaten Banjarnergara tahun 2005, karena sebagian besar ibu hamil merencanakan kehamilannya. ${ }^{7}$ Dari hasil analisi diperoleh $\mathrm{PR}=0,860$ maka ibu hamil yang jarak kehamilannya kurang dari 2 tahun mempunyai risiko untuk terkena KEK dibandingkan dengan ibu hamil yang jarak kehamilannya lebih dari 2 tahun. 


\section{Hubungan Umur dengan kejadian KEK pada ibu Hamil}

Melahirkan anak pada usia ibu yang muda atau terlalu tua mengakibatkan kualitas janin/anak yang rendah dan juga akan merugikan kesehatan ibu. Karena pada ibu yang terlalu muda (kurang dari 20 tahun) dapat terjadi kompetisi makanan antara janin dan ibunya sendiri yang masih dalam masa pertumbuhan dan adanya perubahan hormonal yang terjadi selama kehamilan. ${ }^{2}$ Sedangkan pada umur tua diperlukan energi yang besar pula karena fungsi organ yang melemah dan diharuskan untuk bekerja maksimal, maka perlu adanya tambahan energi yang cukup sebagai pendukung kehamilan yang sedang berlangsung. Sehingga usia yang paling baik adalah lebih dari 20 tahun sampai dengan 35 tahun. ${ }^{13}$ Umur dalam penelitian ini tidak berhubungan dengan kejadian KEK pada ibu hamil, dari hasil penelitian diketahui bahwa umur responden terhadap kejadian KEK pada ibu hamil sebesar $(22,9 \%)$ umur responden berisiko, sedangkan $(77,1 \%)$ umur responden tidak berisiko, dan nilai ( $\mathrm{p}=0,087, \mathrm{PR}=1,6)$.

Hasil penelitian ini sejalan dengan penelitian Agustian Nur Efrinita (2010) bahwa dapat dikatakan tidak ada hubungan yang signifikan antara umur dengan kejadian KEK pada ibu hamil di Kecamatan Jebres Surakarta, karena pada usia kurang dari 20 tahun dapat terjadi kompetisi makanan (gizi) antara janin dan ibunya sendiri yang masih dalam masa pertumbuhan, sedangkan pada usia lebih dari 35 tahun kemampuan tubuh untuk menyerap zat-zat gizi yang dibutuhkan tubuh ibu maupun janin sudah menurun. ${ }^{9}$ Dari hasil analisis dperoleh ( $p=0,076$.) maka ibu hamil yang memiliki umur berisiko terkena KEK mempunyai risiko KEK 3.298 kali dibandingkan dengan ibu hamil yang memiliki umur tidak berisko terkena KEK.

\section{Hubungan Penyakit Infeksi dengan kejadian KEK pada ibu Hamil}

Penyakit infeksi dapat bertindak sebagai pemula terjadinya kurang gizi sebagai akibat menurunya nafsu makan, adanya gangguan penyerapan dalam saluran pencernaan atau peningkatan kebutuhan zat gizi oleh adanya penyakit. Kaitan penyakit infeksi dengan keadaan gizi kurang merupakan hubungan timbal balik, yaitu hubungan sebab akibat. Penyakit infeksi dapat memperburuk keadaan gizi dan keadaan gizi yang jelek dapat mempermudah infeksi. Penyakit yang umumnya terkait dengan masalah gizi antara lain diare, tuberculosis, campak dan batuk rejan. ${ }^{14}$ Penyakit infeksi dalam penelitian ini tidak berhubungan dengan kejadian KEK pada ibu hamil, dari hasil penelitian diketahui bahwa penyakit infeksi terhadap kejadian KEK sebesar $(20,0 \%)$ untuk yang Ya mempunyai penyakit infeksi, sedangkan $(80,0)$ yang tidak mempunyai penyakit infeksi, dan nilai $(p=0,156$, $\mathrm{PR}=1,521)$.

Hasil penelitian sejalan dengan penelitian Marlenywati (2010) bahwa dikatakan tidak ada hubungan antara penyakit infeksi dengan kejadian KEK pada ibu hamil di Kota Pontianak tahun 2010, karena ibu hamil selalu memeriksakan kesehatannya setiap bulan ketenaga kesehatan. ${ }^{11}$ Dari hasil analisis diperoleh nilai $(p=0,643) P R=0,737$ maka ibu hamil yang terkena penyakit infeksi mempunyai risiko relative sama untuk terkena KEK dibandingkan dengan ibu hamil yang tidak terkena penyakit infeksi.

\section{Hubungan Tingkat pendidikan dengan kejadian KEK pada ibu Hamil}

Pendidikan sebagai proses pembentukan pribadi, pendidikan diartikan sebagai suatu kegiatan yang sistematis dan sistemik terarah kepada terbentuknya kepribadian peserta didik. ${ }^{15}$ Faktor pendidikan mempengaruhi pola makan ibu hamil, tingkat pendidikan yang lebih tinggi diharapkan pengetahuan atau informasi tentang gizi yang dimiliki lebih baik sehingga bisa memenuhi asupan gizinya. Tingkat Pendidikan dalam penelitin ini tidak berhubungan dengan kejadian KEK pada ibu hamil, dari hasil penelitian diketahui bahwa tingkat pendidikan responden terhadap kejadian KEK pada ibu hamil sebesar $(68,6 \%)$ tingkat pendidikan rendah SD/SMP, sedangkan $(31,4 \%)$ tingkat pendidikan menengah/tinggi SMA/PT, dan nilai $(\mathrm{p}=0,000, \mathrm{PR}=0,703)$.

Hasil penelitian ini sejalan dengan penelitian Marlenywati (2010) bahwa dikatakan tidak ada hubungan antara tingkat pendidikan dengan kejadian KEK 
pada ibu hamil di Kota Pontianak tahun 2010, karena meskipun tingkat pendidikan tinggi tetapi pada kenyataanya masih kurang mengkonsumsi makanan selama hamil baik dari segi kuantitas (jumlah) maupun dari kualitasnya sehingga menyebabkan ibu mengalami risiko KEK. ${ }^{11}$ Dari hasil analisis diperoleh nilai $(\mathrm{p}=0,147)$ (PR=0,743).

\section{Hubungan Pengetahuan dengan kejadian KEK pada ibu Hamil}

Pengetahuan adalah merupakan hasil tahu dan ini terjadi setelah orang melakukan penginderaan terhadap suatu objek tertentu penginderaan terjadi melalui panca indera manusia yaitu: penglihatan, pendengaran, penciuman, rasa dan raba. ${ }^{16}$ Pengetahuan dalam penelitian ini tidak berhubungan dengan kejadian KEK pada ibu hamil, dari hasil penelitian diketahui bahwa pengetahuan responden terhadap kejadian KEK pada ibu hamil sebesar $(20,0 \%)$ responden tidak bisa menjawab, sedangkan $(80,20 \%)$ responden bisa menjawab, dan nilai $(\mathrm{p}=0,148, \mathrm{PR}=0,666)$.

Hasil penelitian ini sejalan dengan penelitian Halym Surasih (2005) bahwa dikatakan tidak ada hubungan antara pengetahuan dengan kejadian KEK pada ibu hamil di Kabupaten Banjarnegara tahun 2005, dari hasil analisis diperoleh nilai $(\mathrm{p}=0,179)(\mathrm{PR}=0,315){ }^{7}$

\section{Hubungan Pendapatan dengan kejadian KEK pada ibu Hamil}

Pendapatan merupakan faktor yang menentukan kualitas dan kuantitas makanan. Pada rumah tangga berpendapatan rendah, sebanyak 60 persen hingga 80 persen dari pendapatan riilnya dibelanjakan untuk membeli makanan. Artinya pendapatan tersebut $70-80$ persen energi dipenuhi oleh karbohidrat (beras dan penggantinya) dan hanya 20 persen dipenuhi oleh sumber energy lainnya seperti lemak dan protein. Pendapatan yang meningkat akan menyebabkan semakin besarnya total pengeluaran termasuk besarnya pengeluaran untuk pangan. ${ }^{17}$ Pendapatan dalam penelitian ini tidak berhubungan dengan kejadian KEK pada ibu hamil, dari hasil penelitian ini diketahui bahwa pendapatan responden terhadap kejadian KEK pada ibu hamil sebesar
$(68,6 \%)<$ UMR, sedangkan $(31,4 \%)>$ UMR, dan nilai $(\mathrm{p}=0,000, \mathrm{PR}=0,703)$.

Hasil penelitian ini sejalan dengan penelitian Halym Surasih (2005) bahwa dikatakan tidak ada hubungan yang signifikan antara pendapatatan dengan kejadian KEK pada ibu hamil di Kabupaten Banjarnegara tahun 2005, Dari hasil analisis diperoleh $(\mathrm{PR}=5,12)$ maka ibu hamil yang pendapatannya < UMR mempunyai risiko terkena KEK sebesar 512 kali apabila diabndingkan dengan ibu hamil yang pendapatannya $>$ UMR. $^{7}$

\section{SIMPULAN}

1. Faktor-faktor yang berhubungan dengan kejadian KEK pada ibu hamil adalah total energi $(\mathrm{p}=0,004)$ dengan nilai prevalence ratio 0,410 , asupan protein $(\mathrm{p}=0,001)$ dengan nilai prevalence ratio 2,053 bahwa dapat dikatakan dua kali lipat risiko terjadinya KEK pada ibu hamil apabila asupan protein $(<68 \%)$, dan paritas $(0,024)$ dengan nilai prevalence ratio 0,410 .

2. Total energi dalam penelitian ini berhubungan dengan kejadian KEK pada ibu hamil, dari hasil penelitian diketahui bahwa total energi responden terhadap kejadian KEK pada ibu hamil sebesar $(42,5 \%)$ termasuk kurang, sedangkan $(57,1 \%)$ total energi termasuk baik, dan nilai $(\mathrm{P}=0,004$, $\mathrm{PR}=0,410$ ).

3. Asupan protein dalam penelitian ini berhubungan dengan kejadian KEK pada ibu hamil, dari hasil penelitian diketahui bahwa asupan protein responden terhadap kejadian KEK pada ibu hamil sebesar $(48,6 \%)$ termasuk kurang, sedangkan $(51,4 \%)$ termasuk baik, dan nilai $(\mathrm{p}=0,001, \mathrm{PR}=2,053)$ bahwa dapat dikatakan dua kali lipat risiko terjadinya KEK pada ibu hamil apabila asupan protein $(<68 \%)$.

4. Paritas dalam penelitian ini berhubungan dengan kejadian KEK pada ibu hamil, dari hasil penelitian diketahui bahwa paritas terhadap kejadian KEK pada ibu hamil sebesar $(8,6 \%)$ berisiko, sedangkan $(91,4 \%)$ tidak berisiko dan nilai $(\mathrm{p}=0,024$, $\mathrm{PR}=0,410$ ). 
5. Jarak kehamilan dalam penelitian ini tidak berhubungan dengan kejadian KEK pada ibu hamil, dari hasil penelitian diketahui bahwa jarak kehamilan responden terhadap kejadian KEK pada ibu hamil sebesar $(20,0)$ jarak kehamilan berisiko, sedangkan $(80,20)$, jarak kehamilan tidak berisiko dan nilai $(\mathrm{p}=0,148$, $\mathrm{PR}=0,666$ ).

6. Umur dalam penelitian ini tidak berhubungan dengan kejadian KEK pada ibu hamil, dari hasil penelitian diketahui bahwa umur responden terhadap kejadian KEK pada ibu hamil sebesar (22,9\%) umur responden berisiko, sedangkan $(77,1 \%)$ umur responden tidak berisiko, dan nilai $(\mathrm{p}=0,087, \mathrm{PR}=1,6)$.

7. Penyakit infeksi dalam penelitian ini tidak berhubungan dengan kejadian KEK pada ibu hamil, dari hasil penelitian diketahui bahwa penyakit infeksi terhadap kejadian KEK sebesar $(20,0 \%)$ untuk yang Ya mempunyai penyakit infeksi, sedangkan $(80,0)$ yang tidak mempunyai penyakit infeksi, dan nilai $(\mathrm{p}=0,156, \mathrm{PR}=1,521)$.

8. Tingkat Pendidikan dalam penelitin ini tidak berhubungan dengan kejadian KEK pada ibu hamil, dari hasil penelitian diketahui bahwa tingkat pendidikan responden terhadap kejadian KEK pada ibu hamil sebesar $(68,6 \%)$ tingkat pendidikan rendah SD/SMP, sedangkan $(31,4 \%)$ tingkat pendidikan menengah/tinggi SMA/PT, dan nilai $(\mathrm{p}=0,000, \mathrm{PR}=0,703)$.

9. Pengetahuan dalam penelitian ini tidak berhubungan dengan kejadian KEK pada ibu hamil, dari hasil penelitian diketahui bahwa pengetahuan responden terhadap kejadian KEK pada ibu hamil sebesar $(20,0 \%)$ responden tidak bisa menjawab, sedangkan $(80,20 \%)$ responden bisa menjawab, dan nilai $(\mathrm{p}=0,148, \mathrm{PR}=0,666)$.

10. Pendapatan dalam penelitian ini tidak berhubungan dengan kejadian KEK pada ibu hamil, dari hasil penelitian ini diketahui bahwa pendapatan responden terhadap kejadian KEK pada ibu hamil sebesar $(68,6 \%)<\mathrm{UMR}$, sedangkan $(31,4 \%)>$ UMR, dan nilai ( $p=0,000, P R=0,703)$.

\section{DAFTAR PUSTAKA}

1. Depkes RI. 2008. Pedoman Penanggulangan Ibu Hamil Kekurangan Energi Kronis. Jakarta.

2. Soetjiningsih. 2009. Tumbuh Kembang Anak. Jakarta: EGC.

3. Riset Kesehatan Dasar (Riskesdas) tahun 2007.

4. Riset Kesehatan Dasar (Riskesdas) tahun 2010.

5. Riset Kesehatan Dasar (Riskesdas) tahun 2013.

6. Yunita Nugrahini Evi, S.Yusuf, Effendi, M.D.Herawati Dewi, S.Idjradinata Ponpon, Sutedja Endang, C. Mose Johanes, Fuadah S.Yoni. 2014. Asupan Energi dan Protein Setelah Program Pemberian Makanan Tambahan Pemulihan Ibu Hamil Kurang Energi Kronik di Puskesmas Kota Surabaya. Surabaya; Vol.1; No.1. 2014. [20-032017].

7. Surasih Halym. 2005. Faktor-faktor Yang Berhubungan Dengan Kejadian Kurang Energi Kronik (KEK) Pada Ibu Hamil di Kabupaten Banjarnegara. Progrram Sarjana Kesehatan Masyarakat Universitas Negeri Semarang. [19-09-2017].

8. Waluyo, Kusno. 2010. Memahami Gizi Untuk Ibu Hamil dan Ibu Menyusui. Bandung: PT. Puri Delco.

9. Agustian Nur Efrinita. 2010. Hubungan Asupan Protein dengan Kejadian KEK pada ibu hamil di Kecamatan Jebres Surakarta. Program studi D IV Kebidanan Fakultas Kedokteran Universitas Sebelas Maret Surakarta. [21-09-2017].

10. Arisman. 2009. Gizi dalam daur kehidupan. Jakarta: EGC; H.8-9; 15; 20; 163-4.

11. Marlenywati. 2010. Risiko Kurang Energi Kronik (KEK) pada ibu hamil di Kota Pontianak. Program Sarjana Ilmu Kesehatan Masyarakat Universitas Indonesia Depok. [20-09-2017].

12. Siswanto Agus Wilopo, 2010, Hubungan Persepsi Klien Tentang Konseling Keluarga Berencana dengan Pemakaian 
Journal of Holistic and $\mathrm{Health}$ Sciences

Vol.2, No.1, Januari-juni 2018 |43

Metode Kontrasepsi IUD dan Implant. Tesis, UGM, Yogyakarta.

13. D Chandra. 2006. Pengaruh Sosio Demografi, Riwayat Persalinan, dan Status Gizi Ibu Terhadap Kejadian BBLR. Medan: Universitas Sumatera Utara. [25-02-2017].

14. Supariasa, I Dewa Nyoman, et al. 2002. Penilaian Status Gizi. Jakarta: EGC.
15. Umar, Tirtarahardja dan S.L La Sulo. 2005. Pengantar Pendidikan. Jakarta: Rineka Cipta.

16. Notoatmodjo, Soekidjo. 2010. Metodologi Penelitian Kesehatan. Jakarta : Rineka Cipta.

17. Djamilah. A. 2008. Faktor faktor yang berhubungan dengan kekurangan energy kronik di puskesmas jembatan serong Depok: FKM UI. 